Discussion Paper No. 605

\title{
DO THE ELDERLY DISSAVE IN JAPAN?
}

Charles Yuji Horioka

June 2004

The Institute of Social and Economic Research Osaka University

6-1 Mihogaoka, Ibaraki, Osaka 567-0047, Japan 


\title{
DO THE ELDERLY DISSAVE IN JAPAN?*
}

\author{
by Charles Yuji Horioka \\ Institute of Social and Economic Research, Osaka University, and \\ National Bureau of Economic Research, Inc.
}

June 7, 2004

\begin{abstract}
In this paper, I summarize Albert Ando's seminal and ingenious work on the saving behavior of the elderly in Japan and then present some pertinent data and evidence that became available only after Ando did his work in this area. I conclude that the retired elderly in Japan dissave, in accordance with the life cycle hypothesis of saving, and that all of the available data and evidence suggest that the life cycle hypothesis of saving is highly applicable in the case of Japan.
\end{abstract}

Address for correspondence:

Charles Yuji Horioka, Institute of Social and Economic Research, Osaka University, 6-1, Mihogaoka, Ibaraki 567-0047, JAPAN.

Telephone: 81-6-6879-8586

Facsimile: 81-6-6878-2766

E-mail: horioka@,iser.osaka-u.ac.jp

*This paper is dedicated to the memory of the late Albert Ando, who gave so generously of his time and wisdom from the time I was still a graduate student. His advice and kindness will be sorely missed. I am indebted to Shizuka Sekita for her valuable comments and to the Ministry of Education, Culture, Sports, Science, and Technology of the Japanese Government for Grant-in-Aid for Scientific Research number 12124207. 


\section{Introduction}

Together with Franco Modigliani and Richard Brumberg, the late Albert Ando was one of the founding fathers of the life cycle hypothesis of saving, which posits that people work and save when they are young and retire and dissave when they are old. It is not surprising, therefore, that Ando was very interested in whether the elderly dissave, as predicted by the life cycle hypothesis. One of Ando's most ingenious papers is Hayashi, Ando, and Ferris (1988), in which he and his collaborators devise a very clever way of estimating the saving behavior of the elderly who live with their children.

This paper is organized as follows: in section 2, I summarize Ando's seminal work in this area; in section 3, I present some pertinent data and evidence that became available only after Ando did his work in this area; and section 4 concludes.

\section{Professor Ando's Contribution}

Although it is easy to speak about the saving of the elderly in theoretical terms, it is notoriously difficult to measure it in actual practice, and as a result, no consensus has been reached about whether or not the elderly dissave. Just to enumerate some of the problems that arise when one wants to measure the saving of the elderly, one problem is that the unit of observation of the data that are available is almost always the household, and hence it is not possible to obtain direct data on the saving of the elderly individuals who live in multi-generation households. This problem is especially severe in Japan where there are so many extended families (households in which parents and their grown children live together). 
Second, households are usually classified by the age of the household head and since elderly household members are not necessarily the household head (in fact, they usually are not because the head is defined as the household member with the highest income), it is difficult to identify households that have elderly members.

Because of these data limitations, previous researchers were forced to look at data on the saving of households whose head is elderly and to make inferences about the saving of all elderly individuals based on these data. However, the two aforementioned problems apply in the case of such data. First, such data pertain to the household as a whole and include the saving of not only the elderly head but also of his/her spouse, cohabiting children, cohabiting grandchildren, etc. Second, such an analysis totally ignores the saving of elderly individuals who are not household heads (primarily elderly individuals who live with their grown children, hereafter referred to as "dependent elderly") and implicitly assumes that their behavior is identical to that of elderly heads. This is a risky assumption because the majority of the elderly in Japan live with their grown children and are not classified as the household head and because these dependent elderly are very different from elderly heads (for example, they are presumably considerably poorer, on average).

Thus, even if one finds that households headed by an elderly individual in Japan do not dissave, one cannot conclude that all elderly in Japan do not dissave. For one thing, the failure of elderly heads to dissave could merely reflect the positive saving of cohabiting children and other cohabiting family members, and for another, elderly heads are, on average, more affluent than dependent elderly and hence are more likely to be able to save.

The seminal paper by Hayashi, Ando, and Ferris (1988) is an important addition to the literature on the saving behavior of the elderly because it is the first attempt to estimate the saving behavior of elderly persons living in extended families. The ingenious method they use 
to indirectly infer the stock (flow) of saving of such elderly is to assume that the stock (flow) of saving of younger generations living in extended families is identical to that of similarly aged nuclear families and to compute the stock (flow) of saving of older generations living in extended families as the total stock (flow) of saving of extended families minus the stock (flow) of saving of the younger generation. ${ }^{1} \quad$ They apply this method to micro data from the 1984 National Survey of Family Income and Expenditure, which is conducted every five years by the Statistics Bureau of the Ministry of Public Management, Home Affairs, Posts and Telecommunications of the Government of Japan.

Hayashi, Ando, and Ferris (1988) present the results for both the stock and flow of saving, but in my opinion, the results for the flow of saving are more reliable because (1) they do not need to be adjusted for the so-called cohort effect, (2) they do not include intergenerational transfers, and (3) they do not include capital gains and losses, allowing us to focus on out-of-pocket saving. Therefore, I focus on the results for the flow of saving in what follows.

Hayashi, Ando, and Ferris's (1988) results show that the flow of saving of the elderly living in extended families is positive for all but the oldest elderly (i.e., those aged 87). Moreover, their results for the elderly living in nuclear families show that their flow of saving is also positive except for those aged 80 or older. They do find, however, that the single elderly of all ages (who are relatively poor) dissave. Thus, Hayashi, Ando, and Ferris's (1988) results provide some (but not overwhelming) support for the life cycle hypothesis, with the majority of the elderly in Japan continuing to save and only the oldest elderly (i.e., those aged 80 or older) and the single elderly dissaving.

However, the fact that the single elderly of all ages dissave and the fact that most elderly dissave eventually (i.e., when they reach their eighties) provide considerable support for 
the life cycle hypothesis. Moreover, one of the few defects of Hayashi, Ando, and Ferris's (1988) analysis is that it fails to control for the employment status of the elderly. The life cycle hypothesis predicts not that all elderly will dissave but rather that the retired elderly will dissave, and it is highly likely that Hayashi, Ando, and Ferris (1988) would have found more widespread evidence of dissaving if they had focused on the retired elderly, regardless of their living arrangements. Put differently, I believe that the fact that they find any evidence at all of dissaving even though they include the working elderly in their sample constitutes strong evidence on favor of the life cycle hypothesis.

\section{Newly Available Data and Evidence on the Saving of the Elderly in Japan}

In this section, I survey newly available data and evidence on the saving of the elderly in Japan. One analysis that is closely related to that of Hayashi, Ando, and Ferris (1988) and that does take account of the employment status of the elderly to some extent is that of Ishikawa (1988), who uses data from the Family Saving Survey, conducted by the Statistics Bureau of the Ministry of Public Management, Home Affairs, Posts and Telecommunications of the Government of Japan, to analyze the saving behavior of the dependent and independent elderly in Japan. Ishikawa (1988) finds that the presence of cohabiting elderly parents has virtually no impact on the saving rate of young households, which suggests that elderly parents cohabiting with their children are neither saving nor dissaving, but he has no information on whether the cohabiting parents are working or retired. Ishikawa (1988) is able to break down the sample of independent elderly into those who are working and those who are retired and finds that the average total saving rates of salaried worker (including corporate managers), self-employed, and retired independent elderly households are $15.8 \%, 11.5 \%$, and $1.5 \%$, respectively, and that their 
average financial saving rates are $8.5 \%, 4.7 \%$, and $-6.9 \%$, respectively. Thus, he finds, as expected, that the saving rates of working and retired households are very different, with the former being positive and much higher than the latter and the latter being roughly zero in the case of the total saving rate and negative and large in absolute value in the case of the financial saving rate. These results are broadly consistent with Hayashi, Ando, and Ferris's (1988) results and provide limited (but not overwhelming) support for the life cycle hypothesis. However, the data used by Ishikawa (1988) suffer from various defects, and his results would undoubtedly have been stronger if he had had access to better data.

Unfortunately, no direct data on the saving behavior of the retired elderly were available in Japan until recently. The Family Income and Expenditure Survey, conducted by the Statistics Bureau of the Ministry of Public Management, Home Affairs, Posts and Telecommunications of the Government of Japan, collects information on saving rates ("ratios of surplus") by age group of the household head, but the problem is that, until recently, data on saving rates were collected only for salaried worker households (households in which the household head is a salaried worker). Thus, even the data for elderly households pertained only to elderly households whose head is still working as a salaried worker, and no information was available on the saving rates of the retired elderly even though it is their saving rate that is of most interest.

Table 1 shows data on saving rates by age group of the household head for salaried worker households for the 1990-2002 period, and as can be seen from this table, the saving rates of elderly households (households with a head who is 60 years old or older) is lower than that of younger households but is positive and large in absolute magnitude nonetheless, ranging from 13.7 to $22.6 \%$. Looking at trends over time, the saving rates of elderly households declined more or less steadily during the $1995-2002$ period, from $22.6 \%$ in 1995 to $13.7 \%$ in 2002 , but 
was positive and large in absolute magnitude even in 2002. However, these figures are not necessarily contrary to the life cycle hypothesis because they pertain to salaried worker households, not to retired households. What is needed is information on the saving rates of retired elderly households.

Fortunately, the Family Income and Expenditure Survey started collecting saving rate data and other data on various categories of elderly households including retired elderly households in 1995. Thus, it became possible for the first time to know the saving rate of the retired elderly. Table 2 shows data on the saving rates of various categories of retired elderly households for the 1995-2002 period, and as can be seen from this table, the saving rate of all three categories of retired elderly households is negative and large in absolute magnitude. For example, the saving rate of retired households with at least one elderly member ranged from -9.9 to $-20.4 \%$, the saving rate of retired households all of whose members are elderly ranged from -5.2 to $-19.6 \%$, and the saving rate of retired elderly couples ranged from -4.0 to $-18.3 \%$.

Trends over time differ from one category of retired elderly households to another: the saving rate of retired households with at least one elderly member increasing sharply from 1997 from 2001 (in absolute magnitude), before tapering off slightly, while the saving rate of retired households all of whose members are elderly and that of retired elderly couples fell steadily (in absolute magnitude) from 1995 until 2000 before increasing sharply. What all categories of retired elderly households have in common is that their saving rates peaked (in absolute magnitude) in 2001 or 2002.

Thus, it appears that the tendency of the retired elderly in Japan to dissave has always been observed (at least since 1995) and that this tendency has become even more pronounced in recent years. This suggests that the life cycle hypothesis of saving is highly applicable in Japan and that it has become even more applicable in recent years. 
Moreover, data from the Household Survey of Financial Asset Choice, conducted by the Institute of Posts and Telecommunications Policy of Japan Postal show that the retired elderly dissave, on average, in Japan and that even the working elderly dissave, on average, after the age of 70 (see Horioka, et al. (1996)). This constitutes even stronger support for the applicability of the life cycle hypothesis of saving in Japan.

Note, moreover, that various other types of data and evidence also provide strong support for the applicability of the life cycle hypothesis of saving in Japan (see, for example, Hayashi (1986, 1997), Horioka (1984, 1993, 2002), and Horioka, et al. (2000)). For example, Horioka and Watanabe (1997) decompose total household saving in Japan into saving for individual motives and find that saving for retirement is by far the largest component, accounting for a full $62.5 \%$ of total household saving.

As another example, econometric analyses based on time series data as well as cross-country data (see, for example, Horioka $(1989,1997))$ provide strong evidence that the age structure of the population has a significant impact on household, private, and national saving rates, as predicted by the life cycle hypothesis of saving.

As a final example, Horioka (2002) and Horioka, et al. (2000) find that the vast majority of bequests in Japan are either unintended or accidental bequests arising from lifespan uncertainty or are selfishly motivated bequests that are left in exchange for care, attention, and/or financial assistance provided by one's children during old age, both of which are consistent with the life cycle hypothesis of saving.

\section{Conclusion}

The late Albert Ando devoted much of his life and career to analyzing the consumption 
and saving behavior of individuals in Italy, Japan, the United States, and throughout the world, and his work on the saving behavior of the elderly in Japan is merely a small subset of this impressive body of work. I am sure that he will be pleased to know that the data and evidence that become available only after he did his pathbreaking work in this area provides even more support for the life cycle hypothesis than his own work in this area did. His commitment to the life cycle hypothesis of saving was justified after all! 


\section{References}

Hayashi, Fumio (1986), “Why Is Japan's Saving Rate So Apparently High?" NBER Macroeconomics Annual 1986, vol. 1, pp. 147-210.

(1997), Understanding Saving: Evidence from the United States and Japan

(Cambridge, Massachusetts: MIT Press).

; Ando, Albert; and Ferris, Richard (1988), "Life Cycle and Bequest Savings:

A Study of Japanese and U.S. Households Based on Data from the 1984 NSFIE and the 1983

Survey of Consumer Finances," Journal of the Japanese and International Economies, vol. 2, no. 4 (December), pp. 450-491.

Horioka, Charles Yuji (1984), “The Applicability of the Life-Cycle Hypothesis of Saving to Japan," Kyoto University Economic Review, vol. 54, no. 2 (October), pp. 31-56.

(1989), “Why Is Japan's Private Saving Rate So High?” in Ryuzo Sato

and Takashi Negishi, eds., Developments in Japanese Economics (Tokyo: Academic Press/Harcourt Brace Jovanovich, Publishers), pp. 145-178.

(1993), "Saving in Japan," in Arnold Heertje, ed., World Savings: An

International Survey (Oxford, UK, and Cambridge, USA: Blackwell Publishers), pp. 238-278. 
(1997), "A Cointegration Analysis of the Impact of the Age Structure of

the Population on the Household Saving Rate in Japan," Review of Economics and Statistics, vol.

79, no. 3 (August), pp. 511-516.

(2002), “Are the Japanese Selfish, Altruistic, or Dynastic?” Japanese

Economic Review, vol. 53, no. 1 (March), pp. 26-54 (the 2001 JEA-Nakahara Prize Lecture).

; Fujisaki, Hideki; Watanabe, Wako; and Kouno, Takatsugu (2000), “Are

Americans More Altruistic than the Japanese? A U.S.-Japan Comparison of Saving and

Bequest Motives," International Economic Journal, vol. 14, no. 1 (Spring), pp. 1-31.

; Kasuga, Norihiro; Yamazaki, Katsuyo; and Watanabe, Wako (1996),

"Do the Aged Dissave in Japan? Evidence from Micro Data," Journal of the Japanese and International Economies, vol.10, no. 3 (September), pp. 295-311.

and Okui, Megumi (1999), "A U.S.-Japan Comparison of the

Importance and Determinants of Retirement Saving," Economics Letters, vol. 65, no. 3 
(December), pp. 365-371.

and Watanabe, Wako (1997), "Why Do People Save? A

Micro-Analysis of Motives for Household Saving in Japan," Economic Journal, vol. 107, no.

442 (May), pp. 537-552.

; Yamashita, Koji; Nishikawa, Masashi; and Iwamoto, Shiho (2002),

"On the Importance, Nature, and Impact of Bequests in Japan," mimeo., Institute of Social and

Economic Research, Osaka University.

Ishikawa, Tsuneo (1988), "Saving and Labor Supply Behavior of Aged Households in Japan,"

Journal of the Japanese and International Economies, vol. 2, no. 4 (December), pp. 417-449. 
Table 1: Saving Rate by the Age Group of the Household Head, 1990-2002

\begin{tabular}{ccccccr}
\hline $\begin{array}{c}\text { Calendar } \\
\text { Year }\end{array}$ & All ages & $\begin{array}{c}\text { 29 years or } \\
\text { younger }\end{array}$ & $\begin{array}{c}30-39 \\
\text { years }\end{array}$ & $\begin{array}{c}40-49 \\
\text { years }\end{array}$ & $\begin{array}{c}50-59 \\
\text { years }\end{array}$ & 60 or older \\
\hline 1990 & 24.7 & 24.0 & 27.1 & 24.0 & 25.1 & 19.0 \\
\hline 1991 & 25.5 & 25.8 & 27.2 & 25.1 & 25.9 & 21.0 \\
\hline 1992 & 25.5 & 26.0 & 28.3 & 25.2 & 24.7 & 20.7 \\
\hline 1993 & 25.7 & 25.3 & 29.0 & 24.9 & 24.9 & 22.6 \\
\hline 1994 & 26.6 & 27.6 & 28.5 & 25.2 & 28.2 & 20.5 \\
\hline 1995 & 27.5 & 28.0 & 31.3 & 25.4 & 28.3 & 22.6 \\
\hline 1996 & 28.0 & 28.1 & 31.4 & 27.1 & 28.4 & 21.8 \\
\hline 1997 & 28.0 & 30.4 & 31.3 & 26.9 & 28.3 & 22.4 \\
\hline 1998 & 28.7 & 29.5 & 32.8 & 28.0 & 28.7 & 22.5 \\
\hline 1999 & 28.5 & 28.8 & 32.7 & 28.5 & 27.3 & 21.0 \\
\hline 2000 & 27.9 & 25.9 & 32.3 & 29.1 & 26.8 & 17.9 \\
\hline 2001 & 27.9 & 24.0 & 33.8 & 27.5 & 27.0 & 18.4 \\
\hline 2002 & 26.9 & 26.1 & 33.3 & 27.8 & 25.5 & 13.7 \\
\hline & & & & & &
\end{tabular}

Notes: The figures show the saving rates ("ratios of surplus") of salaried worker households.

Source: Statistics Bureau, Ministry of Public Management, Home Affairs, Posts and Telecommunications, Government of Japan, ed., Annual Report on the Family Income and Expenditure Survey (Tokyo: Japan Statistical Association), various editions. 
Table 2: The Saving Rate of the Retired Elderly in Japan

\begin{tabular}{crrr}
\hline $\begin{array}{c}\text { Calendar } \\
\text { year }\end{array}$ & $\begin{array}{l}\text { Retired elderly } \\
\text { households (1) }\end{array}$ & $\begin{array}{l}\text { Retired elderly } \\
\text { households (2) }\end{array}$ & Retired elderly couples \\
\hline 1995 & -11.5 & -9.2 & -9.3 \\
1996 & -10.8 & -6.0 & -5.8 \\
1997 & -9.9 & -6.3 & -5.1 \\
1998 & -11.3 & -6.1 & -5.4 \\
1999 & -14.6 & -7.4 & -6.0 \\
2000 & -16.2 & -5.2 & -4.0 \\
2001 & -20.4 & -14.5 & -14.3 \\
2002 & -17.5 & -19.6 & -18.3 \\
\hline
\end{tabular}

Notes: The figures show saving rates ("ratios of surplus"). "Retired elderly households (1)" denote households in which there is at least one member who is 60 years or older. "Retired elderly households (2)" denote households in which all males are 65 years or older, all females are 60 years or older, and there is at least one member who is 65 years or older. "Retired elderly couples" denote retired couples in which the husband is 65 years or older and the wife is 60 years or older.

Source: Statistics Bureau, Ministry of Public Management, Home Affairs, Posts and Telecommunications, Government of Japan, ed., Annual Report on the Family Income and Expenditure Survey (Tokyo: Japan Statistical Association), various editions. 


\section{Endnotes}

${ }^{1}$ Hayashi, Ando, and Ferris (1988) also use another method-namely, seeing how the stock (flow) of saving of extended families in which the younger generation is of a certain age changes as the age of the older generation increases - but the results based on this method are not discussed here due to space limitations. 